
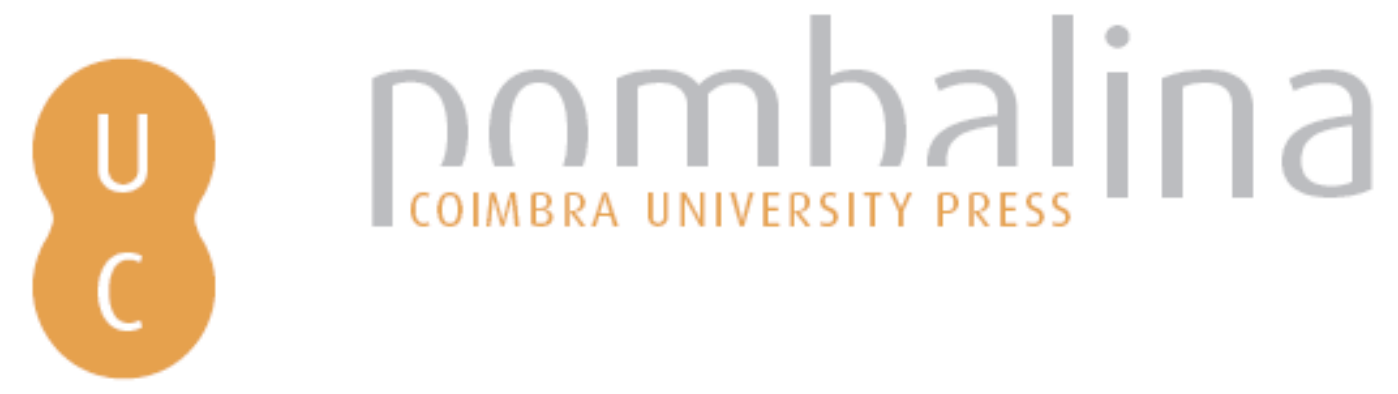

Nos fundamenta da ideia de Europa: humanismo e educação antes da ratio stvdiorvm dos jesuítas
Autor(es):
Soares, Nair Nazaré de Castro
Publicado por: Imprensa da Universidade de Coimbra
URL
persistente:
URI:http://hdl.handle.net/10316.2/38963
DOI:
DOI:http://dx.doi.org/10.14195/978-989-26-0395-7_17
Accessed : $\quad$ 26-Apr-2023 16:16:47

A navegação consulta e descarregamento dos títulos inseridos nas Bibliotecas Digitais UC Digitalis, UC Pombalina e UC Impactum, pressupõem a aceitação plena e sem reservas dos Termos e Condições de Uso destas Bibliotecas Digitais, disponíveis em https://digitalis.uc.pt/pt-pt/termos.

Conforme exposto nos referidos Termos e Condições de Uso, o descarregamento de títulos de acesso restrito requer uma licença válida de autorização devendo o utilizador aceder ao(s) documento(s) a partir de um endereço de IP da instituição detentora da supramencionada licença.

Ao utilizador é apenas permitido o descarregamento para uso pessoal, pelo que o emprego do(s) título(s) descarregado(s) para outro fim, designadamente comercial, carece de autorização do respetivo autor ou editor da obra.

Na medida em que todas as obras da UC Digitalis se encontram protegidas pelo Código do Direito de Autor e Direitos Conexos e demais legislação aplicável, toda a cópia, parcial ou total, deste documento, nos casos em que é legalmente admitida, deverá conter ou fazer-se acompanhar por este aviso.

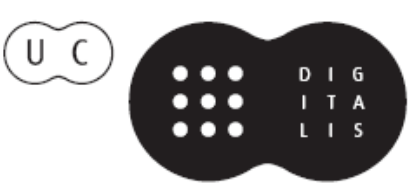


Nair de Nazaré Castro Soares

Santiago López Moreda

Coordenação

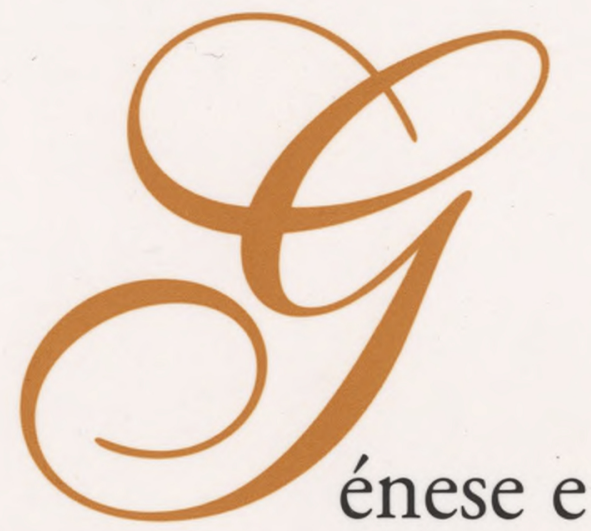

Consolidação da Ideia de Europa

Vol. IV

Idade Média e Renascimento

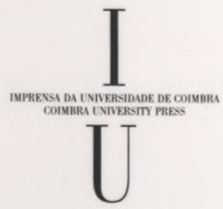

- COIMBra 2009 


\title{
NOS FUNDAMENTA DA IDEIA DE EUROPA HUMANISMO E EDUCAÇÃO ANTES DA RATIO STVDIORVM DOS JESUÍTAS
}

\author{
NAIR NAZARÉ DE CASTRO SOARES \\ (Universidade de Coimbra)
}

A ideia de Europa e a consciência europeia, no Renascimento, estão longe de abarcar um vivo sentimento de pertença a uma comunidade geográfica, histórica e étnica, uma supra-estrutura, diferente e mais vasta relativamente às pátrias individuais, com suas línguas próprias e com todo um conjunto de particularismos que resistem a uma análise filosófica, fundada em princípios universais ${ }^{1}$.

No entanto, a Europa - o orbis noster, o orbis christianus, a respublica christiana, ou ainda a respublica litterarum - afirma-se, na pena dos humanistas, desde Valla, Erasmo, Thomas More, Juan Luis Vives, D. Jerónimo Osório e Damião de Góis, como uma entidade espiritual, como uma realidade cultural que ultrapassa as fronteiras políticas ${ }^{2}$. Esta forma singular de unidade europeia,

'O próprio Erasmo que, nos Adagia (n. 1143: "Quaeuis terra patria") definia pátria como o lugar onde cada um se sente bem, Ubi bene, ibi patria, e em carta, datada de 1 de Fevereiro de 1523 (dirigida ao Deão de Saint-Donatien de Bruges, Marc Lawrin, in P. S. Allen, Opus epistolarum Desiderii Erasmi Roterodami, 12 vol, Oxford, Clarendon, 1906-1958: vol. V, Ep. 1342), pretendia ser um cidadão do mundo inteiro e não de uma só cidade (ciuis totius mundi, non unius oppidi). No en tanto, não se esquece de afirmar Homo batavus sum e, nos derradeiros momentos da sua vida, suspira, com nostalgia, pela sua pátria distante. Neste contexto, se interrogava MARCEL BATAILLON, "Erasmo europeo?", em artigo publicado, em versão espanhola, na Revista de Occidente 58 (Janeiro 1968). Na sua peugada, investigadores como Marie-Madeleine de La Galanderie e Jean-Claude Margolin desenvoverem notáveis reflexões, in La conscience européenne au XVe. et au XVIe. siècles (Actes - Colloque de Paris, 1980), Paris, 1982 (Collection de l'École Normale supérieure de Jeunes Filles, n. 22), p. 296-308 e 240-245, respectivamente.

2 Afirma JEAN-CLAUDE MARGOLIN ("La conception de l'Europe selon Érasme de Rotterdam", in La nascita dell' Europa per una storia delle idee fra Italia e Polonia, a cura di Sante Graciotti, Firenze, Leo S. Olschki Editore, 1995, p. 43-70), p. 49: Ce qu' Érasme 
concebida e vivenciada pelas elites culturais, que radica na consciência de uma herança e pertença comuns, implica contudo a diversidade de modalidades e de identidades de ser europeu.

Plural é necessariamente a Europa que, em diferentes momentos e em diferentes espaços de referência, assiste à queda de Constantinópla, em 1453 - e, com ela, à descoberta do grego, mas também à amputação de toda a sua região oriental -, às guerras de Itália com a consequente redefinição dos estados intra-europeus, à afirmação da ideia de nacionalidade e dos conceitos de pátria e de soberania, às lutas entre príncipes cristãos, ao movimento da Reforma que vem rasgar a indivisível túnica da Igreja unida de Roma, à cruzada contra a ameaça constante do poderio turco-otomano - de que são exemplo as batalhas de Tunes e de Lepanto e as vitórias dos portugueses contra os Mouros e os Rumes, na África e no Oriente - que, enfim, assiste com júbilo às Descobertas marítimas que deslocam a Hispânia da sua posição periférica para o palco do teatro do mundo ${ }^{3}$.

E não fora Portugal, no século de ouro da sua história, pioneiro na descoberta de novos mundos e de outros homens, a nação do "humanismo oceânico"! A gesta lusa e o clima heróico que envolveu a sensibilidade colectiva dos escritores quinhentistas levaram à exaltação individual e colectiva do "homem português", mitificado na figura de Rafael Hitlodeu, o modelo utópico de Thomas More.

Não sem razão, o hino de louvor à humanidade, entoado pelo coro da Antigona sofocliana, 'Há muitas coisas espantosas: nenhuma/ é mais espantosa

apelle orbis noster ou orbis christianus, ou encore respublica christiana dépasse donc les frontiéres politiques [...]. Même quand la Réforme aura opéré son retrait par rapport à l'Église romaine, les «hérétiques» ou frères égarés ne seront pas rejetés de l' orbis christianus, identifié à une Europe de la spiritualité, et non une Europe des nationalités ou des intérêts économiques (ce dernier concept n'ayant d'ailleurs guère de sens au niveau d'une nation prise dans sa globalité). Vide ainda ALAIN MICHEL, "L'idée de Rome et l'idée d' Europe au XVe. siècle", in La conscience européenne au XVe. et au XVIe. siècles cit., p. 265-279; JACQUES CHOMARAT, "Aspects de la conscience européenne chez Valla et Érasme", ibidem, p. 64-74.

${ }^{3}$ Uma referência especial nos merece a afirmação da ideia de nacionalidade e da noção de pátria que adquirem no Renascimento um sentido novo, a par do conceito de soberania que se define e impõe com Jean Bodin. Sobre o patriotismo como noção viva no século XVI, vide J. DELUMEAU, La civilisation de la Renaissance. Paris, 1967, p. 46-57; J. A. MARAVALL, Estado moderno y mentalidad social (siglos XV a XVII), 2 vols., Madrid, 1972: II, p. 457- 525.

Em Portugal, a independência nacional, assente numa monarquia que nem guerras, nem lutas religiosas punham em causa, firmou-se o ideal heróico dos nossos homens de Quinhentos, de par com um alto conceito de pátria que mais se arreigava com a distância dela nos centros do saber europeus, nas paragens longínquas do império, ou mesmo no exílio. Sá de Miranda, na Carta a D. João III (Obras completas, II, Lisboa, 1977, p. 49) sintetizará o sentimento colectivo, nestes termos: «no meo dos corações, esculpidas vossas quinas». 
que o homem ${ }^{, 4}$, poderia resumir a verdadeira força vital do Humanismo, do multifacetado movimento europeu de há quinhentos anos, e servir de lema à exaltação dos seus valores éticos e culturais.

Já Ésquilo ilustrara esta crença no homem, através do mito de Prometeu, que se tornou paradigmático. É que, no Prometeu, o homo poeta e o homo deus são substituídos pelo homo faber, cujo ideal foi enaltecido e revigorado no Quattrocento italiano, a partir de Coluccio Salutati e Leon Battista Alberti. Desde a Antiguidade, o mito de Prometeu era entendido como um símbolo do esforço do homem, no sentido da contínua realização de um ideal de aperfeiçoamento ${ }^{5}$. Platão, no Protágoras, reconhece a importância do mito de Prometeu e aponta nele os três graus de evolução no enriquecimento da ideia de cultura: a civilização técnica, insuficiente na construção da vida em comunidade; a dádiva divina do direito; e a téchnê politikê. Entre estas, o filósofo privilegia a última, ensinada pelos sofistas, pois reconhece à educação o poder de forjar o vínculo espiritual capaz de suster a vida em comunidade e a perenidade da civilização ${ }^{6}$.

$\mathrm{Na}$ verdade, foram os sofistas do século $\mathrm{V}$, que chamaram a atenção para a grande importância da educação humana, da formação retórica, apoiada num curriculum alargado de disciplinas. Defensores da cultura enciclopédica e artistas da palavra, grande foi o seu mérito, não só no plano pedagógico e educativo, como ainda no desenvolvimento da arte oratória, designadamente no que se refere aos fundamentos da lógica e à elaboração dos processos de logomaquia. A partir destes pensadores e profissionais do ensino, a temática educativa ganha actualidade. É retomada e desenvolvida pelos autores do século IV, que lhe fornecem uma base teórica, e sobretudo ainda pelos da época helenística, em que se define o ideal da enkyklios paideia ${ }^{7}$. Os Sofistas foram os primeiros a reconhecer o papel educativo dos Poemas Homéricos. Pela espiritualidade e mundo de valores que encerram, impõem às gerações vindouras ideais educativos, valores morais, sociais e políticos que levaram Platão, na República (606e-607a), a designar Homero "educador da Grécia".

A nível conceptual, a poesia homérica fornece paradigmas que sustentam a argumentação de teorizadores, como Platão e Aristóteles, de prosadores e

${ }^{4}$ SÓFOCLES, Antigona, vv. 332-333.

${ }^{5}$ Manuel de Oliveira Pulquério, "O problema de Zeus no Prometeu Agrilhoado de Esquilo", in Miscelânea de estudos em honra do Prof. A. Costa Ramalho, Coimbra, 1992, p. 37-45; IDEM, "Cultura e ética na Grécia clássica", Máthesis 2 (1993) 9-15.

${ }^{6}$ Ibidem.

${ }^{7}$ Vide I. HADOT, Arts libéraux et la philosophie dans la pensée antique, Paris, Études Augustiniennes, 1984, Chap. VI: «L' "enkuklios paideia”: la notion et son contenu», p. 263-293 . 
poetas, que se debruçam sobre a construção da vida comunitária, sobre a formação e funções de dirigentes políticos ${ }^{8}$. São estes também princípios basilares do Humanismo, retórico e doutrinário".

A literatura pedagógica humanística privilegia, como referência estética e doutrinal: o ensino elementar, nas Leis, o ensino superior, ministrado à classe dos dirigentes, na República, a que os livros VII e VIII da Política de Aristóteles servem de complemento; a Ciropedia de Xenofonte; a obra parenética de Isócrates; a obra retórica e filosófica de Cícero, "o pai do Humanismo", sem esquecer a Carta a seu irmão Quinto; a produção de Séneca, as suas tragédias, epístolas, tratados de filosofia moral e, entre eles, o De clementia, que escreve para o discípulo Nero; o Panegírico de Trajano de Plínio-o-Moço; a Historia natural de Plínio-o-Velho que, pelo teor das suas informações de carácter científico, se tornou verdadeiro "best-seller", na época dos Descobrimentos; a Institutio oratoria de Quintiliano, que impõe o ideal humanístico do uir bonus dicendi peritus (Inst. orat. 12. 1, 1); em língua grega, as obras de Plutarco e Diógenes Laércio, verdadeiras enciclopédias de saber, que satisfazem a curiosidade dos humanistas pela vida das grandes figuras da Antiguidade e transmitem o pensamento das diversas escolas filosóficas; por último, sem deixar de lhe dar o maior relevo, a mensagem dos poetas.

O legado da cultura grega no mundo romano e o génio da sua reelaboração nos autores latinos, da República ao Império, que a Patrística assimila, deixaram marcas indeléveis na cultura ocidental, de que o Humanismo Renascentista é o afloramento mais expressivo ${ }^{10}$.

${ }^{8}$ Mais especificamente no que se refere à temática educativa, os Poemas Homéricos são um verdadeiro manancial de topoi, desde a Antiguidade ao Renascimento: o exemplo de Aquiles, que Fénix ensina "a saber fazer discursos e a praticar nobres feitos" (Il. 9. 442-443); a importância e utilidade da arte retórica - reveladas ao longo da Iliada, quer por Diomedes, "o melhor da sua idade no conselho", a que é consagrado o canto V, quer por Ulisses, "o dos mil artifícios", quer ainda por Nestor, o velho rei de Pilos "de falas harmoniosas"(II. I. 247-249); o valor e significado da poesia, implícitos na arte de Aquiles, ao cantar os feitos dos heróis (Il. 9. 185-191); o papel fundamental atribuído à virtude dos antepassados, em que o mito adquire dimensão histórica; a missão divina do rei, a par da sua humanidade, que a expressão "pastor de povos" traduz; a importância dos exempla, tirados das acções dos heróis míticos do passado, que ditam normas e critérios de orientação para o presente; enfim, o valor do modelo e a educação pelo paradigma, em que à arte da palavra se alia "a moral heróica da honra". Vide e. g. H. I. MARrou, Histoire de l'éducation dans l'Antiquité, Paris, Éditions du Seuil, ${ }^{6} 1965$, p. 41.

9 Vide NAIR N. CASTRO SOARES, O príncipe ideal no século XVI e a obra de D. Jerónimo Osório, Coimbra, INIC, 1994, p. 15-37.

${ }^{10} \mathrm{Ibidem}$, p. 38 sqq. 
Notável a redescoberta de textos essenciais da Antiguidade clássica e o empenhamento e afã dos primeiros humanistas na sua busca - Petrarca, Boccacio, Salutati, Poggio. Conhece-se a correspondência deste último com os monges de Alcobaça, no sentido da aquisição de exemplares existentes neste mosteiro".

Foi nesta altura que se encontraram os tratados ciceronianos De oratore, Brutus e Orator, bem como a Institutio oratoria de Quintiliano e o Diálogo dos oradores de Tácito ${ }^{12}$. Através destes tratados, o homem renascentista aprendia o sentido essencial da retórica, assumida como valor de relação humana e meio de expressão da consciência humanística, que se traduzia também na busca de um ideal de estilo, capaz de conferir dignidade e beleza ao discurso. São os primeiros humanistas italianos, empenhados na vida pública das suas cidades e na formação integral dos concidadãos, que impõem ao mundo culto os padrões de uma educação aristocrática. Os studia humanitatis dão o maior valor ao elemento pessoal. Deixam de limitar o seu âmbito aos auctores medievais e abrem-se à literatura, à história, à poesia, à filosofia e até à arte da Antiguidade Clássica. O novo curriculum, alargado a todos estes saberes e às artes da pintura, escultura, arquitectura e desenho, figura já no Panepistemon de Angelo Poliziano ${ }^{13}$. Intencionalmente, a filosofia moral torna-se um traço característico da vida intelectual deste período, de par com o conhecimento da história e do direito, disciplinas que preparam para a vida activa ${ }^{14}$. Fizera-se ouvir a voz de Cícero, no De oratore, que acreditava na importância da lição dos antigos, na força dos seus exempla, no conhecimento do direito civil, por isso os recomendava na formação do orador ${ }^{15}$. Esta mensagem entendeu-a bem

${ }^{11}$ Vide R. SABBADINI, Le scoperte dei codici latini e greci nei secoli XIV e XV, 2 vols., Firenze, 1967 [repr. anastática da ed. de 1905]; e ainda o estudo de AIRES A. NASCIMENTO, "Poggio e o seu interesse por códices de Alcobaça", Revista da Faculdade de Letras de LisboaVolume de homenagem ao Prof. J. V. de Pina Martins, 5a s. 13-14 (1990) 37-40.

${ }^{12}$ A partir de Pier Paolo Vergerio (1370-1444), autor do primeiro tratado pedagógico, na verdadeira acepção da palavra - quer pelo teor prático da sua doutrina, quer pela real divulgação que conheceu em toda a Europa -, impunham-se, como cartilha, os seguintes textos clássicos: a obra de Cícero, que, no seu sincretismo, fazia a sintese do pensamento retórico e filosófico da Antiguidade grega; a Institutio oratoria de Quintiliano e o De liberis educandis de Plutarco.

${ }_{13}$ PETER BURKE, The italian Renaissance (culture and society in Italy), Cambridge, ${ }^{3} 1987$, p. $51-62$.

${ }_{14}$ Vide e. g. P. O. Kristeller, "Umanesimo filosofico e umanesimo letterario", Lettere Italiane, 14 n.4 (1962) p. 391; sobre a dimensão histórca e jurídica do humanismo quatrocentista italiano, vide e.g. D. R. KELLEY, "Legal humanism and the sense of history", in Studies in the Renaissance, 13 (1966) 184 e sqq.

${ }^{15}$ Cic. De or. 1.5: Tenenda praeterea est omnis antiquitas, exemplorum uis, neque legum aut iuris ciuilis scientia negligenda est. 
Coluccio Salutati, no seu De nobilitate legum et medicinae, onde faz a exaltação da vida da ciuitas, que as leis ordenavam ao bem comum. Na linha da tradição aristotélico-tomista, em convergência com a doutrina platónica, e sob o signo do franciscanismo e do scotismo, Salutati será o pregoeiro do ideal de vida activa e integrará com Leonardo Bruni e Leon Battista Alberti a primeira geração do humanismo civil italiano ${ }^{16}$.

$\mathrm{Na}$ verdade, o interesse que o direito romano suscitava na Europa, de que foram intérpretes os primeiros humanistas, foi um dos aspectos essenciais na evolução do processo histórico ${ }^{17}$. A communis opinio, que se impunha aos juristas medievais como critério de verdade, é substituída pela perícia interpretativa dos humanistas, com base no conhecimento das bonae litterae e no uso da ciência dialéctica. Em Itália, Lorenzo Valla, e a seguir Poliziano, são os primeiros a aplicar o método filológico na interpretação do direito justinianeu, cheio de incoerências e aspectos nebulosos, e a conferir rigor científico ao texto jurídico.

Em Portugal, o Humanismo inicia-se, a passos largos, desde a Dinastia de Avis. Também entre nós, nesta altura, se verificou o incentivo do estudo do Direito. Aliás cabe aos próprios reis, desde D. João I, esse incentivo, ao colocarem, nos cargos importantes da administração do reino, juristas, formados nas universidades europeias, sobretudo em Bolonha ${ }^{18}$.

Nos alvores do nosso Humanismo, vêm de Itália para Portugal os educadores de D. Afonso V, Estêvão de Nápoles e Mateus de Pisano. Mais tarde chega Justo Baldino, que seria encarregado de cantar em latim a gesta lusa, sem que levasse a efeito tal empresa.

D. Afonso V, educado por seu tio, o Infante D. Pedro - o "Infante das sete partidas", que foi regente do reino dede 1439 a 1446 -, encarna o binómio

${ }^{16}$ Vide B. L. UlLman, The humanism of Coluccio Salutati, Padova, 1963, p. 28 e sqq.; FRANCESCO COLASSO, "Umanesimo giuridico", Umanesimo e Scienza politica (Atti del Congresso Internazionale di Studi Umanistici, Roma-Firenze, 1949), a cura di Enrico Castelli, Milano, 1951, p. 57-58.

${ }^{17}$ WALTER ULLMANN, Radici del Rinascimento (tr. Ital. do original: Medieval foundations of Renaissance Humanism). Roma-Bari, 1980, e. g. p. 71; 136; 208-209; 222-225; FRANCESCO COLASSO, "Umanesimo giuridico" cit., p. 57-58.

${ }^{18}$ Notável documento da abertura de Portugal à Europa culta e a sua ligação aos centros de saber europeus e aos seus reputados mestres é o documento sobre a sucessão do Morgado de Góis. Vide Pareceres quatrocentistas de juristas da Escola de Bolonha sobre a sucessão do Morgado de Góis em Portugal. Nota Introdutória e organização de MARTIM DE ALbUQUeRQUe. Tradução de MIGUel PINTO DE MENEZES, Revista da Faculdade de Direito da Universidade de Lisboa (Suplemento - 2007), Coimbra Editora, 2008. 
"armas e letras", do maior significado no Renascimento. Era um rei bibliófilo, melómano, amante das artes, viajante incansável, protector da Universidade. Durante o seu reinado, vê sairem a lume as Ordenações Afonsinas, a primeira compilação de leis do reino. Louvado pela sua cultura intelectual, organiza, no Paço da Alcáçova, em Lisboa, o núcleo da futura Livraria Real, que abre, pela primeira vez as portas ao público. Por outro lado, na sequência da queda de Constantinopla e em resposta ao apelo à cruzada do Papa Calisto III, notabiliza-se pelas campanhas militares no Norte de África, onde conquista Alcácer Ceguer (em 1458), Arzila e Tãnger (em 1471), o que the valeu o cognome de "Africano"19.

No que se refere à educação, os nobres, sobretudo, mandam educar os filhos para fora do reino, facto que levou os procuradores do povo a pedirem a D. Afonso V, nas cortes de 1473, e a D. João II, nas de 12 de Novembro de 1481, que se limitassem as tenças e pensões régias concedidas aos estudantes.

Assim se ia formando um escol de juristas e letrados que seria o suporte da administração régia, cada vez mais burocratizada. Desde as cortes de 1481-1482 - em que D. João II ascendia ao poder, assumindo o Estado como um valor transpersonalizado -, que a velha monarquia tradicional de laivos feudais se convertia aceleradamente em "Estado moderno", centralista, forte e mercantil. A modernização e desenvolvimento do aparelho de Estado, quer no plano interno, administrativo, judicial e militar, eram acompanhados, no plano externo, da definição de uma política ibérica e do incremento da expansão ultramari$\operatorname{nar}^{20}$.

Neste contexto, D. João II vai fomentar e patrocinar a formação intelectual e a preparação destes súbditos para a tarefa da governação, com a concessão de bolsas a estudantes, nomeadamente na Itália ${ }^{21}$. Se é conhecida a presença de portugueses, em finais do século $\mathrm{XV}$, na Universidade de Paris - como observam, nos seus estudos, Joaquim Veríssimo Serrão e Luís de Matos ${ }^{22}$-,

${ }^{19}$ Vide SAUl ANTÓNIO GOMES, D. Afonso $V$, Lisboa, Círculo de Leitores-Colecção "Reis de Portugal", 2006. Sousa Viterbo - "A cultura intelectual de D. Afonso V", in Arquivo Histórico Português, 2 (1904) 255 -, afirma: «Ele tinha a paixão dos livros, estimava as ciências e as artes e comprazia-se no convívio e correspondência dos eruditos do seu tempo, a quem incitava nos sues trabalhos, galardoando-os merecidamente».

${ }^{20}$ Bartolomeu Dias dobra o Cabo da Boa Esperança, em 1487, e em Junho de 1494 assina-se o tratado de Tordesilhas, que salvaguarda para os portugueses não só a Índia, mas a futura Terra de Vera Cruz, o Brasil.

${ }^{21}$ A. D. DE SOUSA COSTA, "Estudos superiores e universitários em Portugal no reinado de D. João II", Biblos 63 (1987) 253-334.

22 JOAQUIM VERISSIMO SERRÃO, Relações históricas entre Portugal e a França (1430-1481), Paris, 1975, p. 49-52; Luis DE MATOS, Les portugais à l'Université de Paris entre 1500 et 1550, Coimbra, 1950. 
tais como Frei João Claro, Diogo de Gouveia, Diogo Ortiz e Pedro Margalho, no entanto o seu número não é suficiente para se poder falar de uma corrente regular, como acontecerá anos mais tarde ${ }^{23}$.

O Humanismo italiano do Quattrocento, iniciado já antes com Petrarca, influencia de forma directa, os estudantes que D. João II manda estudar nas universidades italianas e intercede por eles junto de humanistas como Poliziano, a quem encomenda a celebração em latim da gesta lusa. Entre estes portugueses que estudaram com Poliziano contam-se grandes humanistas, Aires Barbosa, o introdutor do ensino do grego em Salamanca, que depois de jubilado nesta universidade se torna mestre dos futuros cardeais D. Afonso, D. Henrique e do infante D. Duarte; Luís Teixeira, mestre do futuro rei D. João III, Martinho de Figueiredo, autor de comentário - segundo os métodos e as lições que recebera de Angelo Poliziano, em Itália - do Livro I da História Natural, editado em 1529.

No último quartel do século XV, em 1485, chega Cataldo Parísio Sículo a Portugal, a convite de D. João II, para educar o seu filho bastardo D. Jorge. Na altura da sua chegada, este humanista encontra já, entre nós, homens cultos e peritos na língua latina. Em 1481, a 31 de Agosto, o Bispo de Évora D. Garcia de Meneses, proferira em Roma perante o Papa Sisto IV um discurso que teria merecido a admiração de humanistas como Pompónio Leto que o ouvira discursar $^{24}$.

Mas é a Cataldo que se deve o primeiro manifesto, publicado entre nós, em defesa do latim humanístico contra a barbárie estilística do latim medieval, na linha de Lorenzo Valla. Este manifesto surge em carta dirigida a D. Fernando de Meneses, escrita em fins de 1499 ou em Janeiro/Fevereiro de $1500^{25}$. Nesta carta, não falta o louvor dos poetas e entre todos Virgílio, que as crianças devem ler e assimilar desde tenra idade - tal como recomenda Santo Agostinho, no primeiro livro da Cidade de Deus -, para que não mais o esqueçam, e invoca a lição de Horácio (Epistulae, I, 2, 69-70): 'a vasilha conservará, por

${ }^{23}$ Luis DE MATOS, ibidem, p. 5.

${ }^{24}$ Jacopo Sadoleto ofereceu a Gaspar Barreiros este discurso que tinha enchido de admiração Pompónio Leto - a dar crédito ao testemunho inserto na Corografia de Gaspar Barreiros ("Carta-prefácio a Jorge Coelho"). Vide Chorographia de alguns lugares que stam em hum caminho, que fez Gapar Barreiros ó anno de M.D.XXXXVJ. Começãdo na cidade de Badajoz em Castela, te à de Milam em Italia.... Impresso em Coimbra por Ioã Aluarez impressor da Vniversidade, \& por mandado do doctor Lopo de Barros...M.D.LXI. Este discurso de D. Garcia de Meneses abre a Antologia de Latim renascentista em Portugal de AMÉrico COSTA RAMALHO (Lisboa, ${ }^{2} 1994$ ), p. $2-25$.

${ }^{25}$ AMÉRICO COSTA RAMALHO, ibidem, p.41-53. 
muito tempo, como se fosse recente, o odor de que uma vez se embebeu, ${ }^{26}$. Os métodos da moderna pedagogia, utilizados por Cataldo, dão os melhores resultados, a ajuizar pela excelência dos seus alunos ${ }^{27}$.

Em 1495, morre D. João II. Disputa-se a sucessão ao trono entre o filho ilegítimo do monarca, o discípulo de Cataldo, D. Jorge de Lencastre, e o primo e cunhado do rei, o Duque de Beja. É este que ascende ao poder. D. Manuel, o Venturoso, assistirá, no seu reinado, à chegada de Vasco da Gama à Índia, em 1498, e, em 1500, à descoberta do Brasil. Chega-se ao epílogo dessa longa história de descobrir. Vive-se o fausto e o luxo da corte mais prestigiada da Europa, que sustenta a ociosidade e a mania nobiliárquica dos cortesãos, numa Lisboa exótica e cosmopolita ${ }^{28}$. O Mosteiro dos Jerónimos e a Torre de Belém tornam-se símbolos da grandeza do império e impõem um estilo arquitectónico que recebeu a designação de manuelino. A corte é animada nos seus serões pelo teatro de Gil Vicente - que a rainha D. Leonor, viúva de D. João II protegia -, pela música, em que D. Manuel era aficcionado, pela poesia palaciana. Até aos moços negros da corte mandava o rei ensinar a Gramática.

A corte, sentida como meio ideal para a realização das virtudes humanas, a que deu viva voz Garcia de Resende, no "Prólogo" ao Cancioneiro Geral, publicado em 1516, requer «cavalleros blandos i enseñados», no dizer de Sá de Miranda, na dedicatória do Epitalâmio pastoril a António de Sá no casamento de sua filha ${ }^{29}$. Era a ilustração viva dos ideais proclamados por Il cortegiano,

${ }^{26}$ Estes versos de Horácio figuram com frequência nos tratados pedagógicos dos autores do Renascimento, como é o caso de Erasmo e, entre nós, Diogo de Teive. Um aspecto deve, a este propósito, ser referido: Cataldo toma a defesa da poesia, alegando diversas autoridades. Entre elas figura S. Basílio Magno, autor do opúsculo intitulado De legendis antiquorum libris, na tradução de Leonardo Bruni Aretino. Os autores cristãos da Patrística são assim considerados a par dos clássicos. Além disso, é aconselhada, «para inteligência da Sacra Página», a leitura dos escritores e poetas da Antiguidade pagã». Ibidem, p. 45.

${ }^{27}$ Vide NAIR N. CASTRO SOARES, "Cataldo e Resende: da pedagogia humanista de Quatrocentos à influência de Erasmo", In Actas do Congresso Internacional do Humanismo português: Cataldo e André de Resende (Lisboa, Centro de Estudos Clássicos, 2002) 311-340.

${ }^{28}$ As fontes de riqueza, que sustentavam canais de consumo e não de investimento, o abandono da agricultura, a expulsão dos judeus e o seu massacre em Lisboa, em 1506, iriam contribuir a passos largos para a descapitalização interna, verificada nos reinados de D. João III - que se viu obrigado a abandonar as praças de África-e, de forma dramática, no reinado de D. Sebastião. O tratado De regis institutione et disciplina de D. Jerónimo Osório (1572) denuncia de forma insistente esta realidade, e.g. H. OSORII Opera omnia, Romae, 1592: I. 528.20-530.30.

${ }^{29}$ Veja-se a dedicatória do Epitalâmio pastoril a António de Sá no casamento de sua filha, in Poesias de Francico de Sá de Miranda. Edição feita sobre cinco manuscriptos ineditos e todas as edições impressas, acompanhada de um estudo sobre o Poeta, variantes, 
obra dedicada a D. Miguel da Silva, considerado por Baldassare Castiglione modelo de urbanidade ${ }^{30}$. Boscán depressa a divulgará em língua castelhana. O sentido da urbanitas que as humaniores litterae conferem, também entre nós é posto ao serviço dos anseios cortesanescos de grande número de letrados e de membros da fidalguia ${ }^{31}$.

A política educativa de D. Manuel que, em 1508, confere Novos Estatutos à Universidade, enquadra-se num vasto plano: se até então o ensino se concentrava fundamentalmente em duas cidades, Lisboa e Coimbra, num esforço concertado entre a coroa e a Igreja, D. Manuel tenta suprir as carências a que ficava sujeita a população do norte e sul do país. Leva, então, a efeito um projecto de instituir Colégios em Braga, Guimarães e Évora.

Em 1509, o Arcebispo de Braga, D. Diogo de Sousa, um dos discípulos de Cataldo, cria nesta cidade o Colégio de S. Paulo, com o apoio de D. Manuel, que só vemos a funcionar cerca de $1532^{32}$. O Colégio de Guimarães viria a ser criado em 1512. Em 1517, o Colégio de S. Tomás, no Mosteiro de S. Domingos em Lisboa, e, em 1520, um Colégio em Évora.

No entanto, é com D. João III que as instituições de cultura nacionais vão conhecer uma reforma por assim dizer sistemática, que corresponde ao generalizado entusiasmo europeu pelas Humanidades a que a imprensa veio dar um notável contributo ${ }^{33}$.

notas, glossário e um retrato por CAROLINA MICHAËLIS DE VASCONCELOS, Halle, 1885, p. 501, onde se encontra o passo citado; vide ainda, a este propósito, a carta de António Pereira Marramaque a Diogo de Castro, referida por EUGENIO ASENSIO, Estudios Portugueses, Paris, 1974, p. 168.

${ }_{30}$ Vide SYlvie Deswarte, Il 'perfetto cortegiano' D. Miguel da Silva, Roma, 1989.

${ }^{31}$ Lembro, entre as principais, a poesia de Sá de Miranda, a epístola em verso De uita aulica de André de Resende, a Ropicapnefma de João de Barros, as comédias Aulegrafia e Eufrosina de Jorge Ferreira de Vasconcelos. Também as representações dramáticas escolares não são alheias a esta tendência moralizadora e interventiva, de que é exemplo a tragédia Sedecias, composta pelo $\mathrm{P}^{\mathrm{e}}$ Luís da Cruz, para ser representada em Coimbra, por ocasião da visita de D. Sebastião.

${ }^{32}$ Sobre a sua orgânica e plano de estudos, vide AVELINO DE JESUs COSTA, 'D. Diogo de Sousa, novo fundador da cidade de Braga', Distrito de Braga, Ano I, 2-4 (1961) 477-533.

${ }^{33}$ De uma importância singular é o contributo da imprensa na pedagogia humanista. Em Coimbra, já antes de 1537, ano da transferência da Universidade, existiam os prelos de Santa Cruz. Em data que se fixa entre Fevereiro de 1530 e Abril de 1531, Germão Galharde monta a imprensa do Mosteiro e ensina a sua arte aos Cónegos regrantes. Em 1534 aparecem pela primeira vez em Portugal os caracteres gregos, na Imprensa de Santa Cruz de Coimbra, sendo ainda escrito à mão o Grego da Oratio pro rostris de Resende, que sai a lume, em Lisboa, neste mesmo ano. Por carta de 5 de Julho de 1539, D. João III, ciente da importância do livro como instrumento fundamental do ensino e desenvolvimento cultural 
Expressiva do Humanismo português, na primeira metade do século XVI - em que transparece todo o entusiasmo pela renovação e modernidade que Portugal abraça - é a oração que André de Resende pronuncia na Universidade de Lisboa, em $1534^{34}$. As preocupações pedagógicas, neste discurso, integram-se no quadro das reformas educativas estruturais que desde o tempo de D. Manuel se faziam sentir através dos estatutos novos, conferidos à Universidade de Lisboa, da abertura de novas escolas, do incremento cultural que procurava atingir a dignidade e a altura da grandeza do império atlântico.

Se o programa de estudos, que as orações académicas, de estilo ciceroniano, preconizavam, era praticamente o mesmo, desde a oração de Cataldo em Bolonha $^{35}$ e a do seu discípulo D. Pedro de Meneses - proferida na Universidade de Lisboa, na presença do rei D. Manuel, em 1504 -, dirá, com razão, Joaquim de Carvalho que no Renascimento «a designação das disciplinas só tinha de medieval o nome, porque a matéria e a didáctica com que foram ensinadas já se apresentam com o selo da modernidade» ${ }^{36}$.

Sobretudo a partir da oração de André de Resende - que manifesta a maior elaboração individual no género e a maior desenvoltura e segurança na

da Academia, concede aos livreiros da cidade do mondego que «tyverem suas temdas com copia de liuros das çiemçias» que se lêem na Universidade "guozem de todollos priujlegios \& liberdades» que têm os "estudamtes \& offiçiães da dita vnyversidade» (Vide MÁRIO BRANDÃO, Documentos de D. João III, Coimbra, 1937, vol. I, p. 155-156). Por alvará de 21 de Março de 1548 , o monarca confirma e aprova o contrato celebrado, por seu mandado, entre o reitor Frei Diogo de Murça e os impressores João de Barreira e João Álvares (ibidem, vol. III, p. 141-142).

${ }^{34}$ Vide L. ANDREAE RESENDII LVSITANI Oratio pro rostris pronunciata in Olisiponensi Academia Calendis Octobribus MDXXXIIII - edição moderna, André de Resende, Oração de sapiência, Tradução de MIGUEL PINTO DE MENESES. Introdução e notas de A. MOREIRA DE SÁ. Lisboa, 1956

${ }^{35}$ É da sua autoria a Oração em louvor de todas as ciências e da cidade de Bolonha, editada em Epistolae I, em 1500: CATALDO, Epist. I, h $5 v^{\circ}-6 v^{\circ}$; i-i $3 v^{\circ}$. A exemplo de Cataldo, muitas orações se proferiram, no século XVI, na Universidade, no Colégio das Artes e também nos Colégios dos Jesuitas. Ao longo dos tempos, permanece inalterado o modelo ciceroniano destas orações, em que o elogio das letras segue designadamente o Pro Archia; o ideal do homem culto, virtuoso, perito na arte de bem falar é dado pelas recémencontradas obras retóricas de Cícero e Quintiliano.

${ }^{36}$ JOAQUIM DE CARVALHO, "Pedro Nunes, mestre do Cardeal Infante D. Henrique", in A cidade de Évora 21-22 (1950), p. 6. Segundo a ordem que se tornou tradicional desde Alcuíno, o trivium era constituído pela Gramática (isto é, o estudo do Latim, que se alargou ao Grego e ao Hebraico e incluía a Poesia), a Dialéctica e a Retórica. Para se ajuizar do desenvolvimento e do alcance destas disciplinas, vide e. g. B. WEInBERG, Trattati di Poetica e Retorica del Cinquecento, a cura di..., 3 vols., Bari, 1970-1972. O mesmo acontece com as disciplinas do quadrivium que era constituído pela Aritmética, a Geometria, a Astronomia e a Música (consistindo esta última na aprendizagem do cantochão e respectiva teoria). 
apresentação da matéria - todas se vinculam a verdadeiros topoi temáticos, que se exprimem pelos mesmos exempla ${ }^{37}$.

Apesar de tudo, a perfeição estilística e temática, revelada por Resende nesta oração, sem esquecer o vivo apelo ao cultivo do Grego, a defesa da gramática e as críticas ao ensino tradicional documentam bem a evolução do género e o estádio de desenvolvimento intelectual e cultural do nosso país.

André de Resende, pelas funções que desempenha na corte, a partir de 1533, como mestre de príncipes, vai ter um papel importante na nova orientação do ensino em Portugal. No seu ardor pedagógico, o Eborense contribuiu para criar o ambiente propício às ideias reformadoras de D. João III. $\mathrm{O}$ rei que, com seu irmão Afonso, foi leitor de Erasmo - como sabemos pelo Erasmi encomium de Resende (vv. 207-210) - manifestou o desejo de convidar o Mestre de Roterdão para vir ensinar em Coimbra ${ }^{38}$, e encarregou Resende de trazer para Portugal os humanistas belgas, Nicolau Clenardo e João Vaseu, seus amigos e reputados professores do Colégio Trilingue de Lovaina.

$\mathrm{O}$ mecenatismo régio é secundado pelo de outras figuras, como o cardeal Infante D. Henrique, que protege o Colégio de S. Paulo em Braga, onde é Arcebispo. Aos cursos de Gramática e Poética, criados em 1537, se vêm a juntar dois anos mais tarde a Retórica, a Filosofia, os Cânones e a Teologia ${ }^{39}$. Neste colégio, ensina cerca de um ano os rudimentos da língua latina Clenardo, o reputado mestre da Universidade de Lovaina - que André de Resende foi buscar a Salamanca, em 1533 -, enquanto João Vaseu, seu amigo, nomeado para a cadeira de Retórica, não chega desta mesma cidade. Com a intenção de

${ }^{37} \mathrm{Um}$ aspecto é relevante nestas orações académicas: as proferidas antes de meados do século XVI impõem-se como verdadeiros manifestos humanistas contra a barbárie medieval, insensível à beleza e elegância clássicas, na linha das Elegantiae linguae latinae de Lorenzo Valla. As posteriores, têm como preocupação dominante a orientação religiosa, ou melhor, teológica, a que não são alheias as relações entre política e cultura; a definição do ideal do governante e a sua acção concreta, no aspecto educativo e administrativo, na sua acção evangelizadora, no seu empenhamento na cruzada contra o Turco, na manutenção da paz e concórdia internas. Exemplificativas da evolução que se considera a essência do nosso movimento humanista são as orações de André de Resende de 1534 e de 1551.

${ }^{38}$ Cf. a declaração de Damião de Góis perante a Inquisição. Vide, a este propósito, MarCel bataillon, Études sur le Portugal au temps de l'Humanisme, Coimbra, 1952, p. 89. A testemunhar a simpatia de Erasmo pelo possível futuro Mecenas, ficou a dedicatória a D. João III das suas Chrysostomi lucubrationes, na sua edição de 1527 , retirada em edições posteriores.

${ }^{39} \mathrm{O}$ Arcebispo, que tinha por dever do seu cargo promover a instrução, eleva as escolas de Braga a Estudo geral e manda vir mestres de reinos estrangeiros. Sobre a provisão do Infante-arcebispo e sua execução, vide M. GONÇALVES CEREJEIRA, $O$ Renascimento $\mathrm{em}$ Portugal. II - Clenardo. O Humanismo, a Reforma, Coimbra, 1975, p. 116 
suprir às necessidades dos alunos, publica Vaseu, em 1538, uma Collectanea Rhetorices, com um prefácio-dedicatória ao Cardeal Infante D. Henrique. Transferido este para a mitra de Évora, os humanistas belgas acompanham-no. Nesta nova cidade, apreciará Clenardo «muitos varões doutos tanto na língua grega como latina, a ponto de que nem na própria Salamanca se encontrará quem as fale tão correntemente» ${ }^{40}$. A capital alentejana contaria agora com a presença destes pedagogos, que vinham juntar-se a André de Resende, também ele discípulo do humanismo europeu que teve como principal mentor Erasmo, o educador da Europa ${ }^{41}$. Os métodos didácticos, que visam o ensino directo do latim como língua viva, de que são seguidores Resende, Clenardo e Vaseu, são os da moderna pedagogia, muito semelhantes aos que irão ser adoptados mais tarde pelos jesuítas 42 .

Clenardo, o filólogo brabantino, que troca Lovaina, o seu "dulce Lovanium", pela Hispânia, na esperança de aprender o árabe, além das gramáticas hebraica e grega - esta de grande projecção em toda a Europa e adoptada nos colégios europeus da Companhia de Jesus - é autor de uma gramática latina e de uma edição do Livro I de Tito Livio ${ }^{43}$. A sua gramática latina tem a particularidade de se adequar ao ensino directo que ministrava, em que era privilegiada a oralidade, pelo recurso aos colloquia e à recolha de sententiae dos grandes autores. Desta sua pedagogia, na linha de Erasmo, nos dão testemunho ainda as suas cartas a Rugero Réscio, a Vaseu, e à Cristandade ${ }^{44}$.

Assim, em Évora, exerceram o seu magistério, junto de príncipes e nobres ou em escolas públicas, André de Resende, Clenardo, Vaseu e Diogo Sigeu ${ }^{45}$

${ }^{40}$ IDEM, O Renascimento em Portugal I- Clenardo cit., p. 274.

${ }^{41}$ Vide JEAN-CLAUDE MARGOLIN, Érasme précepteur de l'Europe, Paris, 1995.

André de Resende, antes de ir estudar para Lovaina, fora aluno de Estêvão Cavaleiro - autor da Noua grammatices Marie Matris Dei Virginis ars, cuius author est magister Stephanus Eques Lusitanus (1516), um documento do humanismo gramatical, entre nós. Resende fora ainda aluno de Aires Barbosa e Antonio de Nebrija, grandes mestres de filologia, de renome europeu.

${ }^{42}$ Sobre a importância do ensino de Clenardo - a que se encontra associado o de seu amigo Vaseu - e sobre o seu método pedagógico, idêntico ao de Erasmo e Mathurin Cordier, vide o meu artigo "A literatura de sentenças no Humanismo Português: res et uerba", in Actas do Congresso internacional sobre Humanismo Português na época dos Descobrimentos (Coimbra, 9 a 12 de Outubro de 1991), Coimbra, 1993, p. 384-385.

${ }^{43}$ M. GONÇALVES CEREJeIRA, O Renascimento em Portugal, II cit., 153-165, maxime, p. $160-164$.

${ }^{44}$ Ibidem, I cit., "Apêndice", p. 235 e sqq.

${ }^{45}$ Diogo Sigeu de Toledo veio para Portugal em 1543 e foi, na corte, além de secretáio da correspondência latina, mestre de retórica do Príncipe João e outros moços fidalgos, entre os quais avultam D. Teodósio de Bragança e seus irmãos. Vide, sobre Diogo Sigeu e suas filhas, CAROLINA MiChaËlis DE vasconcelos, $A$ Infanta D. Maria de Portugal 
- o pai de Luisa Sigeia, uma das figuras femininas que, com sua irmã Ângela, com Paula Vicente e Joana Vaz ilustra o círculo da Infanta D. Maria, a que já se chamou Academia feminina portuguesa. É esta um testemunho vivo da educação ministrada entre nós, tal como em Itália, Espanha e Inglaterra, às filhas da aristocracia, a que a teorização de Leonardo Bruni, no seu De studiis et litteris liber tinha dado o tom ${ }^{46}$.

Também os colégios universitários hieronimitas de Penha Longa e da Costa, junto de Guimarães, conhecem grande prestígio. Em 1535, por ordem do rei, Frei Diogo de Murça, que obtivera em Lovaina o "bonnet doctoral" em Teologia, vem dirigir um colégio em Penha Longa, onde os religiosos estudariam as ciências. Em 1537, o mesmo monarca muda o Colégio para o Mosteiro de Santa Marinha da Costa. Para ajuizarmos da importância do Colégio da Costa, basta ler os seus regulamento e as disciplinas aí leccionadas ${ }^{47}$. A equivalência perfeita aos graus conferidos aos estudantes da Universidade de Coimbra, leva à reclamação do seu reitor, aliás atendida pelo rei $^{48}$.

Mas é Coimbra, por excelência, a cidadela do saber, para onde D. João III transfere a Universidade, em 1537, e onde funda o Colégio das Artes, em 1548, com a função de facultar uma sólida preparação aos alunos que ingressam na Universidade. Na cidade do Mondego, cantada repetidamente como lusa Atenas, a reforma é liderada por dois obreiros incansáveis, ambos formados na Universidade de Lovaina, Frei Brás de Braga e Fr. Diogo de Murça. Conhecida é a abertura destas duas figuras eminentes do nosso Humanismo Renascentista às correntes de espiritualidade e da pedagogia erasmianas ${ }^{49}$.

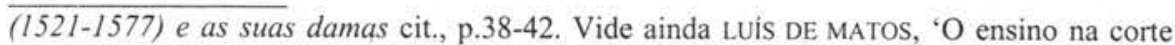
durante a dinastia de Aviz', in O Humanismo Português 1500-1600. Academia das Ciências de Lisboa, 1988, p. 499-592.

${ }^{46}$ A iniciar a tratadística da educação feminina, com grande voga na Europa de Quinhentos - em que o tratado de Vives De institutione foeminae christianae, destinado à educação da futura Maria Tudor de Inglaterra, é o mais representativo - conta-se o De studiis et litteris liber, de Leonardo Bruni d'Arezzo, dedicado no século XV "ad Dominam Baptistam de Malatestis", onde um ambicioso programa de educação intelectual é dirigido a uma filha de familia nobre.

${ }^{47}$ Vide A. MOREIRA DE SÁ, A Universidade de Guimarães no século XVI (1537-1550). Prefácio de Robert Ricard, Paris, 1982. Nestes Colégios, onde leccionam professsores como Inácio de Morais, o autor do Elogio de Coimbra, e Frei Diogo de Murça, encontram-se, entre os estudantes, o Infante D. Duarte e D. António Prior do Crato, filhos ilegitimos do rei D. João III e do Infante D. Luís, respectivamente.

${ }^{48}$ Vide Actas dos Conselhos da Universidade de 1537 a 1557, publicadas por MÁRIO BRANDÃo, vol. I, Coimbra, 1941, p. 2-3.

${ }^{49}$ Cf. e.g. J. V. DE PINA MARTINS, Humanisme et Renaissance de l'Italie au Portugal: les deux regards de Janus, Lisboa-Paris, 1989, p. 433, 436 e 566. 
Coimbra ganha outra feição arquitectónica. Torna-se um centro, onde acorrem os artistas da pedra: João de Ruão e o francês Nicolau Chantraine tiveram oportunidade de fazer aqui verdadeira escola. Marca evidente das proporções deste projecto cultural é a rua de Santa Sofia, a actual rua da Sofia, com a largura que ainda hoje possui, que não existe em tantas outras que pelos tempos fora se foram abrindo, neste velho burgo universitário ${ }^{50}$.

A preocupação da modernidade do ensino era cada vez mais evidente. Na Universidade, funcionavam cursos regulares de Artes e Humanidades, com aulas de Grego, Latim e Hebraico, leccionadas por professores como Vicente Fabrício, Juan Fernández e Mestre Eusébio, respectivamente. As aulas de Grego de Vicente Fabrício, que comentava, nesta língua, Homero, e os alunos lhe respondiam quase só da mesma forma, enchem de admiração Clenardo, ao passar em Coimbra, em Agosto de 1537. O Humanista brabantino fala a um seu compatriota como ficou assombrado com o nouo miraculo ${ }^{51}$. Aliás, o ensino na Universidade das três línguas cultas era prova inequívoca da actualização e europeização das nossas instituições escolares, que seguiam, neste particular, o Colégio Trilingue de Lovaina, onde fora mestre Clenardo e onde estudaram muitos humanistas portugueses, ou o Colégio de França, sob a inspiração de Guillaume Budé, ou ainda a Universidade de Alcalá de Henares, onde seria publicada a Bíblia Poliglota, sob a direcção do Cardeal Cisneros. É que o conhecimento destas línguas torna-se referência indispensável para se ajuizar não só da cultura literária, mas também teológica, jurídica e científica, nesta época. Só através delas era possível o recurso às fontes do saber.

A reforma do ensino em Santa Cruz é levada a cabo por D. Frei Brás de Braga, dez anos antes da transferência da Universidade para Coimbra. À frente da Universidade está Frei Diogo de Murça, confrade e condiscípulo em Lovaina e em Paris do reformador e governador de Santa Cruz. Este jeronomita, que recebeu em 27 de Maio de 1533 o «bonnet doctoral» na Universidade de Lovaina, onde conheceu Clenardo, foi o $4^{\circ}$ reitor da Universidade de Coimbra, desde 5 de Novembro de 1543 a 28 de Setembro de 1555, data em que o rei encarregou o Doutor Afonso do Prado de servir de Reitor (cf. MÁRIO BRANDÃO, Documentos de D. João III, Coimbra, 1941 vol. IV, p. 260). Ilustrativa dos interesses culturais de Frei Diogo de Murça é a relação dos livros que integravam a sua biblioteca obras dos autores clássicos, dos autores sagrados, de humanistas italianos famosos do Quattrocento ao Cinquecento, do humanismo hispânico e europeu, numa abrangência temática e ideológica verdadeiramente notáveis (Vide A. MOREIRA DE SÁ, Livros de uso de Frei Diogo de Murça, Coimbra, 1977).

50 Vide A. NOGUeira GONÇALves, "Os Colégios Universitários de Coimbra e o desenvolvimento da arte", in A sociedade e a cultura de Coimbra no Renascimento, Coimbra, 1982, p. 223-237.

${ }^{51}$ Vide M. Gonçalves Cerejeira, O Renascimento em Portugal I- Clenardo e a sociedade portuguesa (com a tradução das suas Principais Cartas), Coimbra, ${ }^{4} 1974$, p. 114. 
A criação do Colégio das Artes, inaugurado a 21 de Fevereiro de 1548, trouxe da Schola Aquitanica, do Colégio de Bordéus, um escol de humanistas portugueses e estrangeiros de reputação europeia, como Georges Buchanan, Guillaume de Guérente, Nicolas Grouchy, Elias Vinet, Diogo de Teive e o Principal Diogo de Gouveia - a quem Montaigne, aluno do Colégio da Guiena coloca acima de todos os Principais de França. Caberia a Arnaldo Fabrício proferir a oração de Laudes litterarum, na tradição das que se proferiam na Universidade, desde os tempos em que se encontrava sediada em Lisboa ${ }^{52}$.

Apesar de seguir o modelo tradicional, vale a pena referir o conteúdo deste discurso que reflecte bem, dentro da especificidade portuguesa, a mundividência europeia, em que o movimento humanista se afirma e floresce ${ }^{53}$. Nele estão patentes a modernidade do curriculum apresentado, garantia da actualidade do ensino no Colégio das Artes; o orgulho na gesta marítima dos Viri Lusitani e a consciência do seu contributo no alargamento do conhecimento e do saber universais; o mecenatismo do rei, defensor da religião e cultor da paz.

Fabrício, nesta oração inaugural, confessa-se imitador, não simiesco, de Cícero, autor privilegiado na ratio studiorum do Colégio das Artes, e proclama a excelência e a utilidade da res litteraria, suporte da vida em colectividade, através do direito, das leis, da moral. Enunciadas as disciplinas do quadrivium, trata das ciências que visam o aperfeiçoamento da linguagem, no dizer do autor - as que compõem o trivium: a Gramática, a Dialéctica, a Retórica, definidoras da eloquência -, e por fim ainda a Jurisprudência, a Medicina, a História ${ }^{54}$.

${ }^{52}$ Vide Quatro orações latinas proferidas na Universidade e Colégio das Artes (século XVI). Publicação e prefácio de Luís de Matos, Coimbra, 1937. Além desta Oração de Arnaldo Fabrício (p. 1-23), figuram ainda nesta obra a oração de Belchior Beleago, proferida no dia 1 de Outubro de 1548, na abertura da Universidade (p. 25-49); a de André de Resende, proferida no Colégio das Artes em 28 de Junho de 1551, como panegírico de D. João III (p. 51-66); e a de Hilário Moreira, pronunciada na Universidade, em 1552 (p. 67 $-92)$, e de 1552.

${ }^{53}$ A oração do francês Arnaldo Fabrício - um dos humanistas que acompanharam André de Gouveia de Paris para Bordéus e seguidamente para Coimbra - profundamente inspirada na tradição didáctico-pedagógica greco-latina, e’ sobretudo na obra retórica de Cícero, vai ser um marco de referência para as futuras orações e designadamente para a de Belchior Beleago, proferida na abertura da Universidade, no dia 1 de Outubro do mesmo ano de 1548 .

${ }^{54}$ É este um curriculum tipicamente humanista, na linha do enunciado no Panepistemon de Angelo Poliziano, que se tinha alargado aos vários ramos do saber, incluindo as artes da pintura, da escultura, da arquitectura e do desenho.

Note-se, na oração de Arnaldo Fabrício, a importância conferida à disciplina da História, num país que com frequência dava a conhecer ao mundo, em língua latina, a sua gesta contra os defensores do islão, o mesmo islão que punha em perigo a unidade da 
Ao panegírico régio segue-se, por fim, o do Principal André de Gouveia, enaltecido na sua sabedoria e prudência, nas suas qualidades de grande pedagogo, demonstradas na direcção de colégios com a importância do de Santa Bárbara, em Paris, e o da Guiena, em Bordéus, donde viera para Coimbra.

O regulamento da Schola Aquitanica, da autoria de André de Gouveia, que elevou o Colégio de Bordéus a um dos mais afamados da França, serviu de base ao magistério dos «bordaleses» no Colégio das Artes em Coimbra. Escrito em latim, não houve sequer necessidade de o traduzir para português ${ }^{55}$. Apesar disso, existem dois documentos em que o monarca regulamenta o funcionamento desta instituição, o Regimento do Colégio das Artes de 16 de Novembro de 1547 e os Statuta de 26 de Abril de 1548, que em nada colidem, nas suas disposições normativas, com o Regulamento da Schola Aquitanica e, em muitos passos, são semelhantes, ou mesmo coincidentes ${ }^{56}$.

Todos estes regulamentos são complementares e tratam da organização do ensino, que inclui o plano de estudos, as disciplinas a leccionar e suas matérias, de acordo com o progressivo grau de dificuldade, as obras e compêndios adoptados e outros aspectos de carácter pedagógico, de acordo com o modus parisiensis, o mesmo que foi adoptado por reformistas e jesuítas ${ }^{57}$.

Europa, enquanto príncipes cristâos se digladiavam entre si. Neste ano de 1548 sai a lume o Commentarius de rebus in India apud Dium gestis do seu colega Diogo de Teive, que exalta os feitos dos portugueses no cerco de Diu de 1546. Sobre a modernidade do ensino em Portugal, traduzido no curriculum alargado que as orações de sapiência testemunham e os próprios estatutos regulamentam, vide NAIR N. CASTRO SOARES, "Humanismo e História. Ars scribendi e valor do paradigma", Máthesis 1 (Viseu, 1992) 153-169.

${ }^{55}$ Vide o confronto entre estas duas instituições que partilharam métodos pedagógicos e corpo docente, in: CodINA MIR, Aux sources de la pédagogie des jésuites. Le 'modus parisiensis', Roma, 1968, p. 192 e sqq.

${ }^{56}$ Vide o "Regimento do Colégio das Artes de 16 de Novembro de 1547", in: FranCISCO LeITÃo Ferreira, Noticias Cronológicas da Universidade de Coimbra, II Parte (1548-1551), Coimbra, 1944, p. 283-308 e em MÁRIO BRANDÃo, Documentos de D. João III, 4 vols. Coimbra, 1937-1941: vol. III, p. 108-117.

${ }^{57} \mathrm{O}$ modus parisiensis - que acompanha o sucesso do ensino em instituições como o Colégio de Santa Bárbara em Paris, o da Guiena em Bordéus e o Colégio das Artes em Coimbra - vai conhecer a maior difusão também nas escolas protestantes da Europa central, por influência de Johan Sturm, e vai impôr-se também nos Colégios Jesuitas que irradiaram por toda a Europa.

Assente nos princípios da ordem e do exercício, o modus parisiensis, com vista a uma formação integral, física, intelectual, moral e religiosa, foi iniciado nas escolas humanísticas dos Irmãos da Vida Comum e posto em prática em Paris, nas primeiras duas, três décadas do século XVI, por pedagogos como Johan Sturm, Mathurin Cordier e George Buchanan. Sturm, célebre reformador do Ginásio de Estrasburgo e autor de uma vasta obra pedagógica e de um famoso tratado De literarum ludis recte aperiendis (1538), vai influir significativamente na formulação dos métodos pedagógicos e na Ratio studiorum dos jesuítas. Mathurin 
O Colégio das Artes, em Coimbra, fazia parte da Universidade como suas Escolas Menores, embora estivesse isento da sua jurisdição. Assim os seus Mestres, oficiais e alunos tinham os mesmos privilégios dos Lentes e estudantes das Escolas Maiores. Segundo o Primeiro Regimento de 16 de Novembro de 1547, o Colégio das Artes devia ter aulas de Latim, Grego e Hebraico, Artes e Matemáticas, com um total de dezanove professores, e destinava-se prioritariamente a preparar os alunos em Latim e Filosofia, habilitando-os a cursar qualquer das Faculdades Maiores de Teologia, Cânones, Leis ou Medicina.

Além das obras que privilegiam o estudo retórico, há ainda a notar as que surgiram nesta altura para o ensino da Filosofia, designadamente para o estudo da Lógica, da autoria de Jorge de Trebizonda e do aristotélico bordalês Nicholas Grouchy. Assim, como bem se pode constatar, já antes dos jesuítas, a par do ensino da retórica, era dado lugar ao ensino científico e ao estudo de Aristóteles ${ }^{58}$.

Cordier e George Buchanan integraram o grupo de mestres que vieram de Paris para Bordéus, a convite de André de Gouveia, juntamente com humanistas portugueses, como João da Costa e Diogo de Teive.

Vide L. Brockliss, "Curricula", in A history of the university in Europe. II - Universities in early modern Europe (1500-1800), Cambridge: Cambridge University Press, 1996, maxime, p. 572; Giuliano Raffo, S. J., La ratio Studiorum. Il metodo degli studi umanistici nei collegi dei gesuiti alla fine del secolo XVI. Introduzione e traduzione dal latino. Roma, 1989; Cf. Ratio Studiorum da Companhia de Jesus (1599). Regime escolar e curriculum de estudos. Introdução, versão e notas por MARGARIDA MIRANDA; Ratio Studiorum, um modelo pedagógico por J. M. MARTINS LOPES S.J., Ed. Alcalá, 2008.

${ }^{58}$ Para uso do Colégio das Artes foi impressa em Coimbra, em 1551 a Dialectica octo tractatus continens de Jorge de Trebizonda. Também no Colégio das Artes, como no Colégio da Guiena, em Bordéus, se adopta o manual Praeceptiones dialecticae (que viriam a ser editadas em Paris, F. Morel, 1557) do aristotélico Nicolas de Grouchy - um dos bordaleses, professor de Montaigne, que vem para Coimbra com André de Gouveia e é o tradutor para francês da História do descobrimento e conquista da Índia pelos Portugueses de Fernão Lopes de Castanheda. Este manual de Grouchy, único usado no Colégio de Bordéus, é uma sequência de silogismos que ilustram virtudes morais, com exempla retirados da Ética a Nicómaco, o mais platónico dos livros aristotélicos. Em Coimbra, para servir de apoio aos seus cursos, Grouchy traduz uma colecção de textos aristotélicos, alguns directamente do grego, outros a partir da tradução de Joaquim Perion (Dialecticae libri tres, Lugduni, apud Antonium Vincentium, 1545), que o próprio Grouchy corrige. A edição desta colecção de textos feita por Grouchy (Coimbra, João de Barreira e João Alvares, 1549), hoje muito rara, existe na Biblioteca Geral da Universidade de Coimbra e compreende três partes distintas: os livros Aristotelis de demonstratione siue de secunda pars Analyticon libri duo - um dos dois livros do Organon, que Aristóteles dedica ao silogismo, os Segundos Analíticos, conhecido na época por Aristotelis de demonstratione (vide edição separada, datada de Paris, M. Vascosan, 1554); uma segunda parte, Aristotelis Topicorum liber; e uma terceira, Aristotelis de reprehensionibus sophistarum liber unus. Vide sobre as edições de Grouchy, 
A reputação internacional dos seus mestres e o alto nível do ensino ministrado, designadamente nas disciplinas literárias, conferiam-lhe um estatuto de instituição de ensino superior, à semelhança dos colégios europeus, com a prerrogativa de conferir graus ${ }^{59}$.

O ensino ministrado no Colégio das Artes, tal como nos colégios europeus, verdadeiras empresas pedagógicas e culturais - em que o Principal tinha como primeira preocupação o prestigio dos mestres, a máxima exigência a nível curricular e o rigor da disciplina - era para os alunos uma verdadeira escola de virtudes ${ }^{60}$. O seu supremo objectivo era formar o carácter e facultar uma excelente preparação nas humaniores litterae - na eloquentia, a arte da palavra posta ao serviço da sapientia, expressão última da humanitas ${ }^{61}$.

Fundamental e indispensável era um domínio perfeito, correcto e elegante da língua latina, a língua de cultura e de comunicação na Europa. Em latim, eram leccionadas as diferentes matérias, pelo que se torna possível a contratação de mestres estrangeiros - e não poucos, oriundos da respublica litteraria europeia, ilustravam, com o seu prestígio, as instituições do saber, em Portugal.

Faziam os estudos preparatórios em cursos de Artes, não só os futuros profissionais de Humanidades, mas os estudantes de Medicina, de Direito e de

FRANCISCO LEITÃo FERREIRA, Notícias Cronológicas da Universidade de Coimbra, II Parte (1548-1551), vol. III, t. I, Coimbra, 1944, p. 346-347.

Sobre a modernidade do ensino da Dialéctica e da Lógica no Colégio da Artes e na Universidade de Coimbra, de acordo com os ensinamentos de humanistas como Lorenzo Valla, Rodolfo Agricola, Jorge de Trebizonda (ficavam com a designação de "lógicos" os alunos cuja principal matéria de aplicação era a dialéctica de Aristóteles), vide J. S. DA SILVA DIAS, "A Universidade na sua História. A propósito da edição dos Estatutos de 1559", Biblos 40 (Coimbra, 1964) 319-360, maxime 323-328.

${ }^{59}$ Vide, sobre o Colégio das Artes, e. g. os estudos de MÁRIO BRANDÃo, O Colégio das Artes, 2 vols., Coimbra, 1924-1933; IDEM, A Inquisição e os Professores do Colégio das Artes, 2 vols. Coimbra, 1948 e 1969; e as reflexões sobre as instituições de ensino e o ambiente académico, as obras de AMÉRICO DA COSTA RAMAlHo, Para a História do Humanismo em Portugal, I (Coimbra, 1988); II (Lisboa, 1994); III (1998); IV (2000).

${ }^{60}$ Sobre a estrutura orgânica e funcionamento dos Colégios universitários europeus, vide DOMENICO MAFFEI E HILDE DE RIDDER-SYMOENS (dir. ), I collegi universitari in Europa tra il XIV e il XVIII secolo. Atti del convegno di studi della Comissione Internazionale per la storia delle università. A cura di Milano, 1991, designadadamente os artigos de: J. M. Fletcher, "The history of academic colleges: problems and prospects"; Jacques Verger, "Collegi e università tra Medio Evo e Età Moderna"; Marie-Madeleine Compère, "Les collèges de l'université de Paris au XVIe siècle: structure institutionelle et fonctions éducatives", maxime, p. 1-17 e 101-115.

${ }^{61}$ Este é o conhecido ideal retórico humanista - inspirado na tradição greco-latina, designadamente em Cícero e Quintiliano - que pretende formar integralmente o aluno e fazer dele um uir bonus dicendi peritus, na definição de Quintiliano (Inst. orat., 12.1.1). Cf. supra n. 12. 
Teologia. A todos o latim abria as portas à universalidade do saber, e não só da Antiguidade, mas da ciência que toda a Europa produzia, que - por não ter ainda atingido um elevado grau de desenvolvimento e especialização - era abarcável pela enorme curiosidade intelectual dos homens desta época. Em 1555, o Colégio das Artes, em Coimbra, era entregue pela mão do humanista Diogo de Teive, emocionado e desiludido, à Companhia de Jesus. Estava assim definida a orientação predominante do ensino em Portugal, até ao tempo do Marquês de Pombal ${ }^{62}$.

Por seu lado, a Universidade de Coimbra, desde 1537, com seus prestigiados mestres, abre-se à modernidade do ensino e adquire renome europeu.

A orientação tomista da Teologia, que reflecte a influência do método salmantino, é introduzida por Frei Martinho de Ledesma ${ }^{63}$. No magistério desta primeira cátedra de teologia, permaneceria o discípulo de Francisco Vitória, durante trinta anos.

Entre os professores de Direito Canónico e Leis, contam-se Martin de Azpilcueta Navarro, famoso em toda a Europa e Manuel da Costa, que também foi poeta. Sabe-se que - apesar das críticas contra Bártolo, Baldo e Acúrsio, como autoridades de direito entre nós, feitas quer por André de Resende, na sua epístola De uita aulica, quer na comédia Eufrosina de Jorge Ferreira de Vasconcelos - o Regimento da Instituta de 17 de Setembro de 1539 é um testemunho inegável de que o método jurídico medieval tinha sido ultrapassado ${ }^{64}$.

São lentes em Medicina figuras como Rodrigo Reinoso e António Luís. $\mathrm{O}$ ensino de então debatia-se entre o tradicionalismo aristotélico e galénico e a experiência. No entanto, os alvarás régios de 16 de Outubro de 1546 ordenavam que os cadáveres dos doentes estrangeiros, mortos no hospital, e dos justi-

${ }^{62}$ Muitos outros colégios foram instalados nas cidades importantes do reino e, ao longo dos séculos XVI e XVII, nas Ilhas e nas longínquas terras do império ultramarino, desde Angola ao Brasil, a Goa, ao Malabar, à China e ao Japão. Ao tempo das perseguição de Pombal, a Companhia tinha espalhados pela vastidão do reino 57 colégios, 12 seminários e uma universidade. Vide FRANCISCO RODRIGUES, História da Companhia de Jesus na assistência de Portugal, t. I, vol. I, Porto, 1931, p. 217-288; 405-430; IDEM, A formação intelectual do jesuita, Porto, 1917, p. 155-176.

${ }^{63}$ Este inicia na Universidade de Coimbra a leitura de S. Tomás em vez de Durando, como por alvará de 26 de Outubro de 1541 ordenara D. João III. Vide MÁRIO BRANDÃO, Documentos de D. João III cit., vol. II, p. 71.

${ }^{64}$ MÁRIO BRANDÃo, Documento de D. João III cit., vol. I, doc. CXIII, p. 188; cf. também, neste particular, Estatutos da Universidade de Coimbra (1559) por SERAFIM LEITE, Coimbra, 1963, cap. 31, «Do modo que lerão os lentes de cadeiras piquenas de Canones e Leis e Instituta", p. 99. 
çados fossem entregues ao lente de Prima de Medicina, então Rodrigo Reinoso ${ }^{65}$.

Em Matemática, o lente mais famoso de todos foi Pedro Nunes, que deu renome à Universidade e ao seu ensino com obras que os prelos não se cansavam de editar ${ }^{66}$.

No que respeita ao alcance científico da actividade pedagógica, em Portugal, apesar do currículo alargado neste domínio, que as orações de sapiência testemunham e os próprios estatutos regulamentam, Joaquim de Carvalho, afirma que a Universidade, na Renascença, se voltou mais para um ensino especulativo e «em vez de ciência fez erudição» ${ }^{67}$. E inclina-se mesmo a pensar que, «à excepção de Pedro Nunes, nenhum mestre defrontou a Natureza com ânimo resoluto e mente despreconcebida ${ }^{68}$. Apesar disso, as disciplinas tradicionais do quadrivium reflectem bem o espírito renovado do saber, pelo que também no domínio científico a Alma Mater do Humanismo cumpriu a sua missão ${ }^{69}$. Na verdade, não poderemos deixar de lembrar a importância das Descobertas maritimas dos portugueses para o desenvolvimento do conhecimento científico, no domínio geográfico, e das ciências da natueza, que os Colóquios dos Simples e Drogas de Garcia d' Orta admiravelmente exemplificam, quer ainda na consciencialização do valor da experiência como suporte fundamental do saber.

Se quisermos fazer um balanço da política cultural de D. João III, temos de referir que, a par do ensino institucionalizado, escolas de gramática latina foram abertas também nos principais centros do país de que Évora é o

${ }^{65}$ Vide MÁRIO BRANDÃO, Documentos de D. João III cit., vol. III, p. 71-72.

${ }^{66}$ J. V. DE PINA MARTINS, "Humanismo e universidade. Livros quinhentistas editados em Coimbra no âmbito dos estudos escolares e sua contribuição para o progresso do Humanismo", in Actas do Congresso sobre História da Universidade no VII Centenário, t. IV, Coimbra, 1991, p. 47-66. O elogio de todos os mestres da Universidade de Coimbra é feito pelo sevilhano Juan Fernandez: Oração sobre a fama da universidade (1548), de Me. João Fernandes, edição, com prefácio, introdução, tradução e notas de JORGE ALVES OSÓRIO, Coimbra, 1967.

${ }^{67}$ Vide JOAQuim DE CARVAlHo, Obra completa cit., vol. III, p. 329-339.

${ }^{68}$ Ibidem, p. 338.

69 Vide LuIS DE albuquerque, "Science et Humanisme dans la Renaissance portugaise", in L'Humanisme Portugais et l'Europe, Actes du XXI Colloque International d'Études Humanistes, ed. Jean Claude Margolin et J. V. de Pina Martins, Paris, 1984, p. 419-435; J. V. DE PINA MARTINS, "Humanismo e universidade. Livros quinhentistas editados em Coimbra no âmbito dos estudos escolares e sua contribuição para o progresso do Humanismo", in Actas do Congresso sobre História da Universidade no VII Centenário cit., p. 60. 
exemplo.. Entre elas, contam-se as "Escolas menores", que funcionavam junto da Universidade de Lisboa, onde se notabilizou pelo seu magistério Jerónimo Cardoso. Lugar de primeiro plano pelas suas diversas obras de carácter didáctico merece este humanista, autor do primeiro dicionário de LatimPortuguês e Português-Latim, o Dictionarium Latino-Lusitanicum et uice uersa Lusitanico-Latinum, impresso em Coimbra nos prelos de João Barreira, em $1569-1570^{70}$.

Os métodos pedagógicos que emprega situam-se na linha erasmiana do aproveitamento dos exempla clássicos e dos adagia - os Adagia do Humanista de Roterdão figuram em apêndice ao seu Dicionarium - que funcionam como entidades argumentativas e estilísticas, ilustrativas da aemulatio e imitatio tão cara aos humanistas. Os alunos de Latinidade, futuros humanistas, eram adestrados na arte da utilização de estilemas, reminiscências verbais e, numa espécie de sincretismo, com um hábil trabalho de intarsio, que era entalhe e transformação, chegavam a novas iuncturae, reveladoras da sua bagagem cultural e da sua originalidade ${ }^{71}$.

Por toda a Europa se cultivam e exercitam por este método os alunos na latinitas. Uma diversificada produção pedagógica, indiciadora dos métodos e ideais retóricos, de que Erasmo se torna paradigma ${ }^{72}$, vai surgir entre nós até finais do século XVI: a edição de um tratado de Erasmo, que facilitava a memorização de loci comunes, na tradição dos Distica Catonis do ensino medieval, por João Vaseu $^{73}$ - autor da já referida Collectanea Rhetorices; a edição coimbrã dos

${ }^{70} \mathrm{O}$ nosso maior lexicógrafo e modelo de pedagogo, Jerónimo Cardoso, tem merecido ser estudado em valiosos trabalhos de leite de vasconcelos, Justino Mendes de Almeida, Paul Teyssier e Telmo Verdelho. Vide a descrição minuciosa das obras didácticas feita por Justino Mendes de Almeida, na Introdução que acompanha a edição Oração de sapiência proferida em louvor de todas as disciplinas de Jerónimo Cardoso, reprodução fac-similada da edição de 1550. Tradução de MIGUEL PINTO DE MENESES. Introdução DE JUSTINO MENDES DE ALMEIDA, Lisboa, 1965, p. 7-18; e o estudo de referência de TELMO DOS SANTOS VERDELHO, As origens da gramaticografia e da lexicografia latino-portuguesa, Aveiro, 1995.

${ }^{71}$ Sobre o método pedagógico utilizado, quer nas instituições académicas quer no ensino particular, para aquisição da latinitas, vide o meu artigo "A literatura de sentenças no Humanismo Português: res et uerba" cit., p. 377-410.

72 Vide a obra de síntese - intencionalmente elaborada para divulgação - dos trabalhos profundos sobre a pedagogia de Erasmo de JEAN CLAUDE MARGOLIN, Érasme précepteur de l'Europe, Paris, 1995.

${ }^{73}$ Index rerum ac uerborum copiosissimus ex Des. Erasmi Roterodami Chiliadibus per Ioannem Vasaeum. Conimbricae, 1549.

No que se refere aos Disticha Catonis, que têm como presumível autor Dionísio Catão do séc. II d. C., cabe-lhes o mérito de terem servido no ensino das 
Colloquia ad meliorem mentem reuocata do mestre de Roterdão, por Juan Fernandez, que the tinha sido sugerida pelo então reitor da Universidade, Frei Bernardo da Cruz, para servir aos mestres de retórica no ensino da latinidade ${ }^{74}$; um Compendium rhetorices ad Damianum a Goes Equitem Lusitanum, dedicado por Erasmo a Damião de Góis - um conjunto de notas de carácter didáctico sobre lugares comuns e schemata retóricos; os Grammatices rudimenta de João de Barros.

Em estreita ligação com esta prática pedagógica, grande divulgação conhecem também as colectâneas de sentenças, que a Antiguidade nos legou, verdadeiros repositórios de doutrina e de topoi literários. A exemplo dos antigos e na tradição dos autores medievais - cujas obras enciclopédicas orientavam o ensino memorizado e dogmático, genialmente ridicularizado por Rabelais $^{75}$-, os humanistas organizavam sistematicamente obras de carácter enciclopédico, Florilegii, Siluae, Viridarii, Cornucopiae, Thesauri, Margaritae, colecções de Apotegmas, de Adagia, a que se ligam nomes como Paulo Manúcio e Erasmo, e, entre nós, D. Francisco de Portugal, Primeiro conde de Vimioso, Diogo de Teive, Diogo Pires, André Rodrigues de Évora, Frei Luís de Granada ${ }^{76}$.

universidades medievais e continuarem a merecer o interesse dos humanistas - Em Lisboa, em 1521, sai dos prelos de Germão Galharde uma tradução desta obra, intitulada Castigos e Exempros de Catom, reveladora do papel que lhe era atribuído na formação retórica e moral da nossa juventude. Com a mesma finalidade, que lhes reconhece Erasmo, os Disticha Catonis figuram no programa de estudos do Colégio das Artes, que deveriam ser memorizados, logo a partir da nona classe (Vide a ratio studiorum do Colégio de Bordéus, da autoria de André de Gouveia, que viria a ser também Principal do Colégio das Artes: Schola Aquitanica. Regulamento de estudos de ANDRÉ DE GOUVEIA, publicado em Bordéus por E. VINET, Coimbra, 1941: nonus ordo, p. 18).

${ }^{74}$ Vide sobre esta obra, história da sua publicação, reconhecimento do valor da lição de Erasmo, no ensino da Retórica, numa época em que o nome do Humanista de Roterdão figurava no Índex expurgatório, Vide JORGE ALVES OSÓRIO, O Humanismo Português e Erasmo (tese de doutoramento dactilografada, apresentada à Faculdade de Letras do Porto), I, Porto, 1978.

${ }^{75}$ Vide Gargantua, XIV. Cf. Oeuvres de F. Rabelais, ed. A. Lefranc ET AL., Paris, 1921-1931: I, p.141, 143-144.

${ }^{76}$ Contam-se entre estas obras as muitas edições quinhentistas de C. Rhodiginus; R. Volaterranus; N. Perottus; Vicenzo Cartari; Gregorius Reish; Domenico Nano Mirabellio; J. Ravisius Textor; Albrecht Von Eyb; Octavianus de Florovantis Mirandula; Jorge Fabricio; Bartolomeo Cassaneo; Joannes Stoboeus; J. Gruter; Nicolaus Liburnius.

Sobre o género apotegmático, sua origem e evolução, sua representação na Idade Média e Renascimento, o estudo mais completo é o de WILHelm Gemoll, Das Apoph- 
Além do estudo directo dos autores clássicos, na língua original, o conhecimento destas obras e a sua assimilação traduz-se na permanente inserção do seu conteúdo na dinâmica criadora do texto literário. O pendor mimético do discurso humanista, em relação a modelos da antiguidade greco-latina, manifestado sobretudo através da arte alusiva e dos loci similes, levaria Marcel Bataillon a afirmar que «no séc. XVI todo o livro corria o risco de se converter em miscelânea»" ${ }^{77}$.

Os princípios que definem os ideais da pedagogia do Renascimento europeu, numa interpenetração perfeita de classicismo-cristianismo, levam-nos a concluir que o processo educativo reflecte, como num espelho, a mundividência humana e os condicionalismos históricos em que se concretiza.

Aliás, a pedagogia humanista não se realiza apenas através de reformas universitárias ou de outras instituições paralelas ou complementares. São os mestres que nelas professam, os livros que se meditam, lêem ou explicam, os manuais, as obras didácticas e os métodos utilizados, os autores seguidos, a escala global, que se impõem aos padrões de sensibilidade do tempo como auctoritas, que são os principais instrumentos de renovação. É nesta medida que o Humanismo Renascentista, movimento europeu de renovação e lição de modernidade, se torna indissociável da pedagogia, que serve a ciência e dignifica o homem.

Neste sentido, e marcante da nossa idiossincrasia, é a consciência da missão que cabe aos portugueses na cultura e civilização universais, aliada à defesa dos valores do mos maiorum, que ditaram uma certa predilecção, entre nós, pela educação moderna de raiz italiana, pela formação integral do princeps, que se pretende uomo universale, culto e bem formado, capaz da sabedoria necessária à orientação do destino colectivo de um povo ${ }^{78}$.

thegma. Literarhistorische Studien, Wien, 1924. Cf. e. g. PAVlvS MANVTIVS, Apophthegmatum ex optimis utriusque linguae scriptoribus libri VIII, Venetiis, 1590; DESIDERIVS ERASMVS, Adagiarum Chiliades, Venetiis, 1508; IDEM, Apophthegmatum opus, Parisiis, 1532.

${ }^{77}$ MARCEL BATAILLON, Erasme et l'Espagne Nouvelle édition en trois volumes. Texte établi de l'édition de 1937 par Daniel Devoto. Edité par charles Amiel, Genève, 1991, p. 678: "Au XVI siècle, d'ailleurs, tout livre courait le risque de se convertir en miscellanée".

${ }^{78}$ Vide naIR N. CaStro SOARES, O príncipe ideal no século XVI e a obra de D. Jerónimo Osório cit., p. 167-188. A temática educativa está presente, na produção quinhentista, desde a Breve doutrina e ensinança de príncipes de Frei António de Beja à Doutrina de Lourenço de Cáceres ao Infante D. Luis e ao Espejo del principe christiano de Francisco de Monzón - que pertencem ao período joanino -, até à imensa produção pedagógica dirigida a D. Sebastião. Tal sucede também por toda a Europa do Renascimento, ao afirmar-se, dentro do modelo da Institutio principis christiani de Erasmo, o género dos Tratados de Educação de Principes como um tema europeu. 
Os nossos tratados de educação de príncipes, cuja obra-prima do género é o De regis institutione et disciplina (1572) de D. Jerónimo Osório - ilustre humanista, com uma notável intervenção político-religiosa na Europa do seu tempo, num primoroso latim - além da temática educativa e da definição da imagem do homem ideal, projectada no ideal do governante, envidenciam o orgulho em ser português e na gesta lusa. São assim um testemunho perfeito da história das mentalidades, documento da história nacional e europeia, reflexo das preocupações e anseios do homem e, em última análise, expressão da sua liberdade e dignidade.

Não é sem razão, por isso, que um dos primeiros tratados humanistas de pedagogia política, Breve doutrina de ensinança de principes de Frei António de Beja, impresso em Lisboa por Germão Galharde em 1525, abre com amplas citações do De hominis dignitate de Giovanni Pico della Mirandola. Impõe-se deste modo o sentido absoluto de modelo e se liga para sempre o ideal do príncipe perfeito ao ideal do homem perfeito, que a humanitas confere.

É que, entre nós, a humanitas - considerada peritia litterarum e scientia rerum - dá voz à lusitana virtus, "mais do que prometia a força humana", que a empresa das Descobertas projectava como imagem e impunha como pedagogia incomparável ${ }^{79}$.

Concluindo, o domínio do latim representa como que um elo vertical, capaz de «abolir o tempo e religar a Antiguidade ao presente ${ }^{80}$. De um ao

${ }^{79}$ Significativa é a oração académica de André de Resende, de 1551. Nesta oração, proferida na presença do Infante D. Luís, no Colégio das Artes, em Coimbra, e dedicada à Infanta D. Maria, para não ser acusado de adulação ao rei, segundo confessa, faz o elogio de D. João III, não em termos abstractos de doutrina política, mas em termos concretos, tomando o próprio rei como centro de reflexão. Alude à vitória da expedição de Carlos V, em Tunes, em 1535, onde se notabilizou o Infante D. Luís; encarece a gesta heróica dos Lusitanos no Oriente; louva o papel das Ordens religiosas na missionação do novo mundo, manifestando um proselitismo cristão que se harmoniza com o espírito de cruzada - revelado sobretudo nas cartas dos Jesuitas, enviadas das mais remotas paragens, da China ao Japão, à Índia e ao Brasil, onde se espelha um verdadeiro ardor evangélico, na transformação da feritas, da gentilitas, em humanitas christiana, em pietas.

Muitas foram as edições de cartas dos Jesuítas, homens cultos, escritas da Índia, do Japão, da China e do Brasil, em castelhano e em português, impressas em Coimbra nos prelos de João Álvares (1555), João Barreira (1562 e 1565), António de Mariz (1570), em Lisboa, na oficina de Simão Lopes (1593) e em Évora na de Manuel de Lira (1598). O título descritivo destas cartas elucida sobre o seu alcance não só religioso, mas também cultural. A portada da edição de Évora é a seguinte: Cartas que os Padres e Irmãos da Companhia de Iesus escreuerão dos Reynos de lapão \& China aos da mesma Companhia da India \& Europa, des do anno de 1549 atè o de 1580 [...]. Nellas se conta o principio, socesso, \& bondade da Christandade daquellas partes, \& varios costumes, \& falsos ritos da gentilidade.

${ }^{80}$ M.-M. DE LA GARANDERIE, 'Érasme. quelle conscience européenne?', in La Conscience européenne cit., p. 302. 
outro lado do continente europeu, toda uma elite formada nas humaniores litterae constitui como que um terceiro poder entre o poder político e o poder religioso, o poder da cultura, que justifica a expressão que virá a empregar Francis Bacon, scientia est potentia ${ }^{81}$. Através do latim, os humanistas movimentam-se pelos diversos centros do saber e são responsáveis pelo progresso da educação e das instituições de ensino, que adoptam programas de estudos similares e impõem o universalismo do pensamento clássico e todo o conhecimento moderno, apoiado na experiência, a uma Europa sufficientissima sibi, no dizer de Sebastião Münster, na sua Cosmografia de $1559^{82}$.

Apesar disso, é, nesta forma singular de unidade europeia, em época de "sino de latim", que, a marcar a diversidade de identidades do ser europeu, se faz a exaltação da língua vulgar, na linha do De uulgari eloquentia de Dante e dos autores do Cinquecento, de que Trissino, Bembo, Castiglione são figuras representativas $^{83}$. E a par de obras monumentais, em prosa e em versos

${ }^{81}$ Vide, a este propósito, ANDRE CHASTEl ET KLEIN, L'age de l'Humanisme, Paris, 1963.

82 Precedido já por Pedro Apiano - que já referira a superioridade da Europa sobre os outros continentes, na sua Cosmographia de 1524, frequentemente reeditada e traduzida -, Sebastião Münster afirma (Cosmographia, Basileae, 1559, p. 40-41) que a Europa, embora mais pequena que as outras partes do mundo, é a mais povoada, a mais fértil e a mais rica em culturas. A Europa basta-se a si própria, tanto na paz como na guerra: ela possui homens bastantes para combater, para trabalhar os campos e para habitar as cidades - Europa sufficientissima sibi. É também da Cosmographia de Sebastião Münster, edição de 1588, provavelmente a primeira, que o historiador DENYS HAY (Europe: The emergence of an Idea, Edinburgh University Press, $1957-2^{\mathrm{a}}$ ed. 1968) retira uma gravura que representa a Europa de maneira alegórica: uma imperatriz coroada, que segura na mão direita a esfera do mundo, encimada por uma cruz, e na mão esquerda um ceptro. Note-se que a cabeça e a cara representam a Hispânia, figuração que surge em Camões, n'Os Lusiadas. Sobre a figura alegórica e a respectiva representação das regiões e países europeus, vide DENYS HAY cit., frontispício e p. 119. Vide ainda J. CEARD, 'L'image de l'Europe dans la littérature cosmographique de la Renaissance', in La Conscience européenne cit., 49-63.

${ }^{83}$ Embora se imponham os modelos italianos - sob a influência de D. Miguel da Silva, o dedicatário do Cortigiano, e de Sá de Miranda -, a "questão da língua" entre nós assume uma intenção expansionista e imperialista, a que a Gramática Castellana (1492) de Nebrija dá o tom. São disso reflexo a Gramática da linguagem portuguesa (Lisboa, 1536) de Fernão de Oliveira e a Gramática da língua portuguesa e o complementar Diálogo em louvor da nossa linguagem (Lisboa, 1540) de João de Barros.

Sobre a especificidade da questão da língua vulgar em Portugal, nas suas diversas conexões relativamente à Espanha e à Itália, vide EUGENIO ASENSIO, 'La lengua compañera del Imperio. Historia de una idea de Nebrija en España y Portugal', in Estudios Portogueses, Paris, 1974, p.1-16; IDEM, Prologo à sua edição da Comédia Eufrosina, Madrid, 1951, p. XL-LII: 'El problema de la lengua'; Introdução de LUCIANA STEGAGNO-PICCHIO a João de Barros, Diálogo em louvor da nossa linguagem, Modena, 1959 (reeditada in La Méthode Philologique. Ecrits sur la littérature portugaise. II. La prose et le théâtre, Paris, 1982, p. 281-313); M. L. CARVALHÃo BUESCU, Babel ou a ruptura do signo. A gramática e os 
inspirados, escritas no prestigiado idioma do Lácio, surgem por toda a Europa obras notáveis nas diferentes línguas vulgares. E é na nobre língua portuguesa que Camões enaltece, com a "arte sublimada" da sua Musa épica, o Reino Lusitano, "quasi cume da cabeça da Europa toda"

Numa palavra, é sobretudo na magnificentia régia, em prol dos studia humanitatis, que protege e promove a mobilidade de pessoas e de saberes, na Europa humanista, ao longo de mais de um século, e que congrega na corte $\mathrm{e}$ nas instituições de ensino, sobretudo em Coimbra, na Alma mater Conimbrigensis, um escol de mestres nacionais e europeus; é ainda no encontro com novos mundos, na evangelização e na globalização do conhecimento e da experiência, que Portugal dá um contributo notável para a afirmação universal, no século XVI, dos fundamenta da ideia da Europa, como a iria conceber Robert Schuman, nas suas raízes culturais, científicas, religiosas, económico-sociais e humanas.

gramáticos do Século XVI, Lisboa, 1984; SYlvIE DESWARTE, Il "Perfetto cortegiano" D. Miguel da Silva, Roma, 1989, p. 78-81.

${ }^{84}$ Camões, Lus.III, 20. 